\title{
ESTILOS ESTRUTURAIS DA REGIÃO DO DOMO DE PITANGA, BACIA DO PARANÁ, SP
}

C.Riccomini

O denominado Domo de Pitanga, localizado na região de Piracicaba-Rio Claro, porção leste da Bacia do Paraná, Estado de São Paulo, constitui um alto estrutural onde estão expostas, do centro para as bordas, rochas sedimentares neopaleozóicas do Grupo Tubarão (Subgrupo Itararé e Formação Tatuí), neopaleozóicas a eventualmente mesozóicas do Grupo Passa Dois (formações Iratí e Corumbataí), mesozóicas do Grupo São Bento (formações Pirambóia e Serra Geral), recobertas pelos depósitos cenozóicos da Formação Rio Claro e coberturas colúvio-aluviais mais recentes.

O mapeamento geológico de detalhe, conduzido na metade ocidental dessa feição. permitiu elaborar uma primeira aproximação de um modelo de evolução estrutural da área, revelando uma história mais complexa do que até agora admitida. São reconhecidas pelo menos seis fases de intensa movimentação tectônica, com idades compreendidas entre o final do Paleozóico e o Quaternário, a saber:

A - eventos sísmicos sinsedimentares, de magnitude elevada $\left(m_{\mathrm{b}}\right.$ provavelmente maior do que 5.5), produzindo liqüefação em depósitos marinhos rasos da Formação Corumbataí, com a injeção, de baixo para cima, de diques clásticos arenosos de espessura decimétrica, orientados preferencialmente segundo a direção NE. Estes abalos estariam provavelmente relacionados à reativação de estruturas mais antigas, das zonas de cisalhamento Guaxupé e Jacutinga e do Lineamento Moji-Guaçú - Dourados, como reflexo das manifestações iniciais da ruptura do Supercontinente Gondvana, no Permiano Superior a Triássico Inferior;

B - extensão NE-SW, generalizada na borda leste da Bacia do Paraná, com a colocação de diques e sills de diabásio da Formação Serra Geral, de idade jurássica superior a

Departamento de Paleontologia e Estratigrafia, Instituto de Geociências, USP. 
cretácica inferior;

C - transcorrência dextral, com binário principal orientado segundo NE a ENE, com compressão NW-SE, gerando falhas transcorrentes dextrais de orientação NW a WNW, NNE e ENE, falhas sinistrais NW, dobras não-cilíndricas, aproximadamente cônicas, abertas, de amplitude métrica, com geratrizes orientadas segundo NNE a NE, além de falhas reversas e, localmente, dobras recumbentes, ambas de direção NE;

D - compressão NE-SW, talvez associada a um binário transcorrente sinistral E-W a WNW-ESE, a qual estariam associadas falhas transcorrentes sinistrais de direção ENE, falhas transcorrentes dextrais NNE e NNW, além de dobras não cilíndricas, aproximadamente cônicas, abertas, de amplitudes decimétricas a métricas, com geratrizes orientadas segundo NW, gerando padrão de interferência tipo "domo e bacia" pela superposição com as dobras da fase anterior;

E e F - manifestações neotectônicas no vale do Rio Passa Cinco, com falhas normais e reversas de direção NE, relacionadas inicialmente à tração NW-SE e posterior compressão coaxial; afetam depósitos de terraços aluviais, mais jovens do que a Formação Rio Claro, esta de idade supostamente neogênica a quaternária.

As fases transcorrentes C e D estão bem impressas em sedimentos das formações Tatuf, Irati e Corumbatal, não tendo sido ainda observadas em arenitos da Formação Pirambóia, talvez pela falta de exposições favoráveis. Acredita-se que estas deformações ligadas à transcorrência sejam posteriores ao magmatismo juro-cretácico, uma vez que as falhas destas fases não se encontram preenchidas, mesmo nas vizinhanças de importantes corpos básicos (diques e sills) da Formação Serra Geral, bem como pela persistência dos padrões de dobramentos, independentemente da distância aos corpos de rochas básicas. Estariam, portanto, compreendidas num intervalo de tempo entre o Cretáceo Superior e o Terciário Inferior.

De outro lado, os falhamentos normais e reversos preenchidos por diques de diabásio, freqüentemente observados em outras partes da bacia, poderiam estar relacionados à deformações tectônicas anteriores ou contemporâneas à colocação dos corpos de rochas básicas.

A continuidade dos levantamentos na metade oriental do domo poderá permitir a reavaliação deste modelo, preliminarmente proposto, além de comprovar se a estrutura é realmente um domo ou outro tipo de feição. 